Portland State University

PDXScholar

Spring 2015

\title{
Conversion and Conversation : Speech and Social Change in Jean Toomer's Cane
}

Travis Grail-Bingham

Portland State University

Follow this and additional works at: https://pdxscholar.library.pdx.edu/honorstheses Let us know how access to this document benefits you.

\section{Recommended Citation}

Grail-Bingham, Travis, "Conversion and Conversation : Speech and Social Change in Jean Toomer's Cane" (2015). University Honors Theses. Paper 132.

https://doi.org/10.15760/honors.132

This Thesis is brought to you for free and open access. It has been accepted for inclusion in University Honors Theses by an authorized administrator of PDXScholar. Please contact us if we can make this document more accessible: pdxscholar@pdx.edu. 
Conversion and Conversation: Speech and Social Change in Jean Toomer's Cane

\author{
Travis Grail-Bingham
}

An undergraduate honors thesis submitted in partial fulfillment of the requirements of:

Bachelor of Arts

in

University Honors

and

English

Thesis Advisor:

Alastair Hunt

Portland State University

2015 


\section{Acknowledgments}

This project could not have been completed without the help of my wonderful and selfless professors. First and foremost I would like to thank Alastair Hunt for agreeing to advise me, and then going above and beyond the call of duty as an advisor. Without our many meetings discussing Cane and theory, I never could have constructed the following pages. I would also like to thank Sarah Ensor, who inspired me to create the first iteration of this project, and stuck by me and advised me throughout all my subsequent attempts at creating the following pages. I would also like to thank Dr. Ruth, for first introducing me to the beauty that is academic analysis of literature, the Honors Department for guiding me through the process, and the rest of the English faculty for guiding me through my collegiate experience. 
"The folk-spirit was walking in to die on the modern desert. That spirit was so beautiful. Its death was so tragic. Just this seemed to sum life for me. And this was the feeling I put into Cane. Cane was a swan-song. It was a song of an end.”

-Jean Toomer (Turner 123).

Situating Cane is always a difficult task. Like its author, the book hovers between identities- it inhabits a middle ground that is not easily defined. Written in 1923 by an author who is often considered African-American ${ }^{1}$, Cane largely meets the criteria to be considered part of the Harlem Renaissance. Cane is also a work that defies many literary conventions, combining poetry and prose in a way that seems most reminiscent of the high modernist movement. Toomer kept in close contact with authors like Sherwood Anderson, and was heavily influenced by the modernist movement ${ }^{2}$. To a large degree it does make sense to situate Cane in the context of high-modernism, but to do so would ignore (or at least marginalize) the racial motivations of the text. Though Toomer did not self-identify as African-American, the text draws heavily from the spirituals and folklore of the African-American community at the time, and foregrounds problems with racial oppression and violence

The fact is that Cane does not fit neatly into either of these movements, but instead seems to inhabit a space around or between them. Though it is a text heavily invested in race, it is not

\footnotetext{
${ }^{1}$ Toomer's racial identity is ambiguous. Born to two-mixed race Americans, Toomer was accepted in both white and black circles during his life. In terms of literary movements he is often considered canonical to black American fiction, but his own views on his race shifted often. In 1922 (one year prior to Cane's publication) Toomer wrote a letter to Claude McKay (editor of The Liberator) in which he states "racially, I seem to have (who knows for sure) seven blood mixtures: French, Dutch, Welsh, Negro, German, Jewish, and Indian. Because of these my position in America has been a curious one. I have lived equally amid the two race groups. Now white, now colored. From my own point of view I am naturally and inevitably American” (Turner 18). Though there is ample reason to consider Toomer an African-American writer, there is also ample reason to question the validity of that claim.

${ }^{2}$ Anderson was to some degree an inspiration for Cane. In an autobiography describing the years surrounding the conception and writing of Cane, Toomer writes "I was strongly influenced, first, by the Americans who were dealing with local materials in a poetic way. Robert Frost's New England poems strongly appealed to me. Sherwood Anderson’s Winesburg, Ohio, opened my eyes to entirely new possibilities” (Turner 120).
} 
written by an author who identifies with any racial group. It fits the paradigm of modernist writing, but is motivated and applicable to aspects of society that are completely separate from the rest of the modernist movement. The critical reception of Cane in regards to its place in literary canon is something that is very much in flux, something that is always open to reinterpretation. I present this in order to give a basic sense of what the text is; it is similar to a Harlem Renaissance text, it draws from High Modernism. It can be considered canonical to either of these movements, but is also striving for something that does not seem to fit neatly into either.

Cane's ambiguity applies not just to its participation in literary movements, but also to its form. The book is composed of three parts; the first two are collections of short stories and poems, the third part, "Kabnis", is somewhere between a novella and a play. However, describing Cane in this way seems reductive; just as the text as a whole inhabits a space of neither/nor in terms of genre, so too do the individual components in terms of form. The stories are incredibly poetic, often employing lyrical tropes and songs as components. The poems also inhabit a space somewhere between poetry and song, and defining them as solely one or the other ignores vital aspects of the text. There is no part of Cane that can easily be read as a single type of text; the whole thing seems to weave in and out of literary forms.

In some ways Toomer's definition of Cane as a "swan-song”(quoted above) is the most accurate description of what Cane is. This definition fits in a number of ways. It works in the traditional sense of the term- as a final work. Cane was Toomer's last major published work, his last announcement of himself to the literary world, his literary "swan-song." Oddly enough it was his first major work as well, his first and last literary announcement- his "birth-song” and his 
"swan-song." Toomer wrote before Cane, and continued to write after Cane, but majority of his writing was unpublished, and there was never any attempt at another project as large as Cane. However, this existence of Cane as a final work was not the impetus of this quote, but rather the idea of a "swan-song" was the impetus for Cane. Toomer composed Cane after his first trip to the South, and after his first experiences with folk-songs and spirituals. There he "realized with deep regret, that the spirituals, meeting ridicule would be certain to die out... The folk-spirit was walking in to die on the modern desert” (Turner 123), Cane was a swan-song for those spirituals, an attempt at singing one last-folk song. This presents a major problem: What does it mean for a written (which is to say non-verbal/oral) piece to be a preservation of an oraltradition? How is the reader to interpret a text that claims to be something other than a text? How can we read a song?

In order to answer these questions it is first imperative that we justify reading Cane as a song in the first place. The claim seems to be inherently self-contradictory; however, it is not by any means a new interpretation of the text. Many critics, throughout the history of criticism of Cane have made note of its relationship to music, its indebtedness to musical structure. There is B.F. McKeever's article "Cane as Blues," which posits that Cane is constructed as a blues piece, there is Bowie Duncan's claim that Cane is "an elaborate Jazz composition," and (most importantly for the scope of this project) there is, Chiji Akoma's claim that Cane is composed through a "spoken-written interface.” Akoma’s claim is that Toomer succeeds in his attempt to compose a swan-song- that Cane's frequent use of the aesthetics of folk-speech takes it outside of the realm of a "novel" and places into the realm of an oral-performance (Akoma 117).

All of this points towards the necessity of focusing on the oral/aural senses when reading Cane. Not only is Cane is a text that is heavily concerned with language, it is also invested in the 
idea of spoken language, that is, in the idea of speech. Unpacking what speech means in Cane is by no means a simple task, as the ways in which speech shows up, and the effects of speech vary considerably throughout the text. Because of its sundry purposes it seems necessary to limit the discussion of speech to a single topic, in this case the role of speech in (and in relation to) oppressive structures. Speech regularly appears, as both event and theme, in the context of oppressive social structures.

Because of this, I will be examining the speech in Cane as it relates to power. Speech and power are, however, ill-defined words when initially presented. They are broad concepts, and in order to accurately examine them it is necessary to limit them to smaller definitions. This project will examine these dynamics through the lens of Hannah Arendt's definitions of speech and power, as well as examining the tangible effects of speech as shown through the text. Arendt's definitions of both speech and power are important to this project because of the way they privilege community. As Cane is, in part, a project that attempts to preserve a dying form of community, (more specifically, a dying form of communal speech) a definition of speech that attends to the communal nature of speech seems most pertinent.

Communal speech, in Cane, is the form of speech that is most productive for social change. That is not to say that it is inherently productive, but that it carries the potential for change. Using Arendt's conception of speech acts as a theoretical backdrop for the language in Cane, I will examine how individualistic speech functions as opposed to a more communal form of speech. The text shows that individualistic speech fails, but that communal speech still carries the potential for action- the potential for change. In order to fully understand this, it is first necessary to understand the Arendtian conception of speech that I am working with, and then turn to the text itself, to examine how it puts forth these ideas. 
In The Human Condition Arendt states that the "revelatory quality of speech and action comes to the fore where people are with others and neither for nor against them- that is, in sheer human togetherness” (Arendt 180). For Arendt in order for speech to conduct itself like action it needs to have a communal aspect. Speech is inherently tied to the speaker, it is the speaker disclosing himself to the world, and responding to the world. This is juxtaposed against what she refers to "mere talk," where the speaker is not disclosing himself, but merely attempting to coerce or control the listener through spoken language. The words of "mere talk" do not disclose the speaker, and so they cannot be manifestations of "speech" (180). That is to say, when the impetus for speech is coercion (when the truth is made irrelevant), or there is a general disregarding of the listener, it is no longer "speech," but is "mere talk" instead. Speech needs to involve both the listener and the speaker as agents, and must disclose the speaker to the listener. This places a distinction between speech as an individual act, and speech as a communal act. An individual speaking for the sake of the individual is a drastically different act than a community speaking (regardless of the intention of the community).

Arendt also posits that speech is action, when it fits this criteria. All true forms of speech are inherently active forms of speech. She posits that "no other human performance requires speech to the same extent as action" (179). What she means by this is that there must be an "actor" in order for there to be an "action"- and in order for there to be an "actor" that person must disclose him or herself. This can only be done through speech, forcing the two to exist in relation to each other. Speech may accomplish many things, but at its baseline it is always the action of disclosure, the act of self-announcement. So speech always performs at least one action, and action always requires speech to truly be an action (179)3.

\footnotetext{
${ }^{3}$ When dealing with speech acts it is important to at least touch upon J.L. Austin, albeit only to explain why I am not using his conceptions. In his lecture "How to Do Things with Words" Austin also posits that speech can be action,
} 
Turning back to Cane there is still the question of what this text is, but now it is important to ask that in terms of what type of language Cane is comprised of. There is a difficult conflation of the individual and the communal with Cane; it is a text composed by a single manbut it is also a text that performs multi-vocality and folk-speech. It is simultaneously an individually created language, and a communally voiced language (to the extent that it is modelled on and constructed with the aesthetics of folk-speech). This conflation of oppositional forms of speech make it important to turn to moments that deal with these two types of speech in order to understand what Cane is attempting to say about speech acts.

The following pages will look at Cane directly with this in mind. I will first look at the poem Conversion from the first section of Cane, and then turn towards "Kabnis” in order to relate the two. "Kabnis" deals directly with the effects of speech in society, and looks at both individual language and communal language. I will read "Conversion” in reference to Arendt's conception of strength, showing how speech can create tangible change, though not always in powerful way. "Conversion” is important as it cements the fact that Cane is a text that is heavily invested in the power of language and of speech, and aware of the potential violence or coercion that speech can accomplish through strength. It is a surreal poem that describes the conversion of an "African Guardian of souls” to Christianity through language. Turning to "Kabnis” I will be examining what Cane has to say about the individual's relationship to speech and power as opposed to the idea of a communal voice, and through “Kabnis” I will show what Cane as a

but his conception is limited to specific speech acts performing specific actions (i.e. saying the words "I do" at a wedding being the act of getting married). This is useful in that it paved the way for linking speech and action, and there are a number of similarities between the two. However, Arendt's conception is more useful for examining power dynamics, Austin’s more useful for a concise description of speech as action. 
whole posits about this dynamic. I will then turn to the short story "Blood-Burning Moon” (also from the first section), which examines communal speech in relation to silence and violence.

By the end of "Kabnis," it is clear that an individually created language is unsuccessful as a "weapon or shield" (Battenfeld 1238) against racial oppression and violence. That is to say Cane shows that what Arendt refers to as "talk" is unproductive for social change. This does not, however, imply that communal speech is a savior, a perfect method for action. Instead, by the end of "Kabnis" the reader is aware that individual language fails, and that communal language has not yet succeeded. The very end of "Kabnis" is a meditation on the idea of an "Amen" vocalized by multiple people, and Kabnis' failure to participate. What this implies is that there is a potential for social change through a communally vocalized language, but that such a form of language has not been attempted well enough for anything to change. The end of "BloodBurning Moon” is similar, ending on a lone woman on the street after a brutal lynching, hoping that the town will come and sing with her, claiming that perhaps this communal act will bring back the lynched man. Both moments show how Cane does not make any definitive claims about the redemptive power of language, but how it gestures towards the potential for action through Arendtian speech. It is not a book that claims that a communal voice is inherently productive and active, but one that claims that an individual voice will get lost. It points towards the redemptive power of language, but does not make a claim that any form of language is inherently redemptive.

Actual acts of communal speech are strangely absent in Cane, yet communal speech is still integral to the text. Instead of describing communal speech acts, Cane performs them. This reading is perhaps most fully explored by the critic Chiji Akoma, in his essay "Cane and the Black Oral Performance Aesthetic." Akoma argues that Cane 
itself is an enactment of folk-speech, of a communal oral tradition. Akoma's reading suggests that the communal speech surrounding Cane is not performed within it, but rather performed by it. The speech acts do not stem from the characters, but from the text itself. Cane, according to Akoma, is not a text that is concerned with folk-speech; it is a "written verbal performance" (120), an enactment of folk-speech.

Akoma begins by addressing the question of genre, asking the question "what is Cane?” Akoma's answer to this question is something of a non-answer, he states that Cane "cannot and need not be read using Western paradigms of literary appreciation. If the performance does not announce itself as such and follows a different structure, why seek a novel?” (117). Akoma's claim is that Cane functions through "a spoken-written interface" (118), using improvisation, speech tropes, and folk tradition to create a performance that is exterior to the form of the novel. This interpretation "constructs the text as one coherent artistic creation” (120), allowing each individual piece to work in unison with the others. The fragmentation of the stories and poems does not work against understanding Cane, but rather aids the reading of Cane as an oral performance. Quoting James Kraft, Akoma points out that "the black aesthetic unity is organic, or self-creating, then the formal unity of Cane... is not affected by Toomer's not originally conceiving of the parts as forming a whole” (qtd in. Akoma 120). The fragmentation, the various literary forms, and the sundry narrators aid in this idea of Cane as a communal performance. The individual pieces speak together in order to create a unified voice.

After pointing out how the form mirrors the oral folklore aesthetic, Akoma goes on to investigate how the content achieves the same ends. This begins with an examination of how Cane uses song to create the overall aesthetic of the text, and "pay homage to the oral performance.” Akoma claims that foregrounding song engages the oral-aural senses, adding to 
the reading of Cane as oral-performance. This changes the form from being strictly textual, to being somewhere in between speech and writing. The use of song also engages the reader as a part of the text, Akoma describes the refrain in the opening story, "Karintha," as "a song that the audience members will be invited to sing” (122). This reading creates Cane as both a text that engages the reader through spoken language, but also one that has the reader co-create the spoken language with the text. It is not simply a performance but the creation of communal speech through song.

The form of speech that Akoma is concerned with is highly reminiscent of Arendtian speech. Folk-speech is inherently communal, inherently shared between multiple people. Folk-speech is not conducted in a way that implies any sort of conversion or coercion, and always attempts to disclose the speakers through a unified voice. This form of folk-speech mirrors Arendt's conception of speech and power, the unified voice is a result of people acting in concert, the listener and the speaker are one and the same, and as such are "neither for nor against" themselves (Arendt 180).

Akoma also points out a highly important fact about Cane- it "invites the reader" to sing along. That is to say, it implicates the reader as a speaker: as a co-constructer of the text. The task of justifying reading a text as a communal speech act is complicated. There is the obvious issue of speech and writing being different forms of language (which Akoma addresses through pointing towards Cane's engagement of the oral/aural senses), and the more difficult issue of the text having a single origin- a single creator. Jean Toomer wrote Cane, which is to say it was an individually created form of language. However, by inviting the reader to "help sing," to perform a speech act with the text, Cane subverts this individual origin. By engaging the reader not only as a passive vehicle 
for the language, but an active constructer, Cane becomes a book with two speakers, a text that is vocalized by a community.

Akoma's reading makes the importance of communal speech visible, but does not fully explain the importance of speech in general. In order for the full weight of speech to be shown I will turn now to the poem "Conversion," as it appears in the first section of Cane. I will examine a passage from "Kabnis," which continues the thoughts presented in "Conversion,” and relates them directly to individualistic speech. Finally I will look at “Blood Burning Moon” which examines silence and violence in relationship to speech. Each one of these moments presents a different form that "talk" can take. The coercive "talk" in "Conversion" mirrors Arendt's conception of "strength;" "Kabnis" examines the pitfalls of "authority," and shows how it differs from power; finally “Blood-Burning Moon” shows the silence of violence, and how speech could serve as a potential solution to violence and silence. ${ }^{4}$

African Guardian of Souls,

Drunk with rum,

Feasting on a strange cassava,

Yielding to new words and a weak palabra ${ }^{5}$

Of a white-faced sardonic god-

Grins, cries

\footnotetext{
${ }^{4}$ Arendt's conception of speech and power are very similar; the distinction being based more on an active/passive dichotomy than a theoretical one. Power, according to Arendt, is something that is always shared, it is a communal state where people are acting in concert. Speech, similarly, relies on the communal- people must be speaking in concert in order for a speech act to be an act. Because Arendt defines speech as an action, and power relies on "acting in concert" (Arendt, On Violence 45), power requires speech to exist. The other modalities described by Arendt (strength, authority, violence) are always in relation to power, much in the same way speech is always in relation with "talk." I posit that "talk" can take on these forms, in the same way that speech can take on the form of power. In other words "talk" is to authority and strength what speech is to power, (violence is somewhat removed from this paradigm, as it is characterized by silence and its instrumental nature, and therefore should not be conflated with vocal acts).

${ }^{5} \mathrm{~A}$ word. Also: talk, esp. of an unnecessary, profuse, or idle nature. (OED)
} 
Amen,

Shouts hosanna ${ }^{6}$. (Toomer 28)

I’ve been shaping words after a design that branded here. Know whats here? M soul. Ever heard o that? Th hell y have. Been shaping words t fit m soul. (Toomer 111)

These two moments are perhaps the most disparate moments in the text in terms of what they say about the autonomy of language. First we have “Conversion” in which language itself (as I explain below) is given control over both the speaker and the listener; then we have Kabnis claiming to have control over language, claiming the ability to "shape" language to his soul. The two moments seem diametrically opposed. However, placing them together highlights necessary complications about spoken language, allowing for a reading that attends to what Cane is actually positing about speech.

On the outside, “Conversion,” it seems to be dealing primarily with the question of religion, and the conversion to Christianity. While not untrue, this reading does not capture the entirety of what the poem is doing. The issue of religious conversion is important, but what is equally important is the question of how that conversion takes place. The conversion itself takes place in two lines- "Yielding to new words and a weak palabra / Of a white-faced sardonic god." These two lines are full of oddities. Aside from the strangeness of describing this conversion as “yielding," the question of what the "Guardian of Souls” is yielding to is very much in play. On a broad level, we are led to believe that it is Christianity, but the language used to describe this conversion points towards language itself. The "Guardian of Souls” yields to "new words and a weak palabra.” The content of these words is never explained fully, a Christian undertone is

\footnotetext{
${ }^{6}$ An exclamation meaning “save now,” was shouted by the Galilean pilgrims when Jesus entered Jerusalem in recognition of His Messiahship (OED)
} 
implied through the last line ("shouts hosanna”), and they relate to a "white-faced sardonic god," but there is no specificity in regards to their content. The implication is that the "Guardian of souls" is yielding to the words themselves, not the content contained within the words. The words themselves are not even made out to be particularly powerful, described in tandem with "a weak-palabra," an almost redundant phrase that implies the language is profuse or idle.

This idle talk is to a large degree without a speaker. It is described as "of a white-faced sardonic God," a genitive phrase that signifies both that this God is speaking, and that this God is being spoken about. Coupled with the poem opening on a somewhat mythic figure of a "Guardian of Souls," either reading seems to be possible. The poem's grounding in reality is not so concrete that the speaker could not be a "God," but the ambiguity of the phrasing makes it impossible to say for sure if this God figure is actually present or only present through speech. Given this, the only verifiable power in the poem is the power of speech and language itself. It is not the "sardonic God" that is being yielded to, but the "weak palabra" itself.

The fact that the act of conversion is described through yielding implies a lack of shared understanding, which is to say, a lack of speech or power. This form of coercive talk is far more akin to Arendt's conception of strength than it is power. Strength is power without community; strength is the individual's ability to persuade or coerce (Arendt On Violence 45). If we read the "sardonic God" as the speaker, then there is direct evidence for a singular voice, if we read the weak palabra as the agent there is still an implication of a singular entity. What this establishes is that strength through talk is capable of coercion, that words can shape souls (Arendt 45).

Which is why it is so jarring when later Kabnis claims the ability to do the opposite, to take words shape them to his own personal soul. Kabnis' monologue opens with a distinction between orators and preachers- creating a binary that places the orator over the preacher. That is 
to say, it places secular language over religious language. An orator, according to Kabnis, speaks for the sake of speech and the individual soul, while the preacher is speaking for a more religious and communal purpose. The orator is speaking for the sake of his own soul- not to engage others in dialogue- he is speaking to himself, for himself.

This moves into a very aesthetically and physically oriented description of speech and language. Kabnis claims his words as "beautiful and golden" and as having a "taste that makes them fine to roll over with y tongue” (111). Kabnis's words are then powerful because of their aesthetic and physicality, in their taste and color. As in "Conversion”, the importance of the language does not consist of its content. The content is at best elusive, and often is not even touched upon; the content is not what gives the language its merit. In "Conversion" the language itself is capable of conversion; with "Kabnis" the beauty of the language is the end goal of the language.

Though these two passages seem diametrically opposed in the ways in which language interacts with the human, they place a very similar value in language itself. In both passages, the text is making a claim about the autonomy of language, and the exteriority of language to its content. The two passages are also pointing to very similar conceptions of the role of or the force of religion in language. In many ways, “Conversion” sets the scene for Kabnis’ diatribe on language. The key to this is embedded in Kabnis' description of a "form" that is "burned int" (111) his soul, and the ambiguity of the "yielding” in "Conversion” (28).

Kabnis' description of the relationship between his language and his soul is complicated by a third component- "th mold that's branded on [his] soul" (111). This "form" or "mold" is branded on, which is to say, supplementary ${ }^{7}$ to his soul. This form, which Kabnis refers to as

\footnotetext{
${ }^{7}$ In a very Derridean sense. This “mold” is simultaneously a substitute for Kabnis' soul, as well as an additional component separate from his soul. The "mold" usurps the soul by intercepting the language initially intended for the
} 
"it,” feeds on words, but not the type of words he would shape to fit his soul. Instead this form feeds on "misshapen, split-gut, tortured, twisted words" (111), words that are not "beautiful and golden” (111), but ugly in the extreme ${ }^{8}$. These “words” are often not directly words, but other forms of action that Kabnis then interprets as words. "White folks," he says, "feed it because their looks are words,” (111) "black niggers feed it because theyre evil and their looks are words" (111) and "this whole damn bloated purple country feeds it because its goin down t hell in a holy avalanche of words” (111). Kabnis’ interpretation of words rests not on the actual spoken act, but on the interpretation of action back into words. This "form” is capable of translating "looks" into words, and feeding off the ugliness of that translation. This adds to the interpretation of speech and language being composed of something beyond speech and language. This reading of non-speech acts as "words" seems similar to the idea of the power of speech lying in something beyond its content. Kabnis’ claim here does not necessarily illuminate what speech is composed of, just continues to extend the possibilities of what can be considered speech.

This supplementary form is not an in-born element of Kabnis’ soul, but rather something that "crept in from a dream” (111). This allows "Conversion” to be a possible origin of the form. “Conversion” is set in a very dream-like place, a mythic “Guardian of souls” drunk, feasting and yielding, in some sort of presence of a "white-faced sardonic God.” The heavy use of ambiguity regarding time, place, and meaning allows the poem to inhabit a dream-like space. In this space,

soul, and by doing so acts as a substitute. At the same time, the soul does continue to exists, despite the "mold", so in this way the "mold" is an additional component of the soul. This conflation of substitute and addition is a perfect model of the Derridean supplement.

${ }^{8}$ The ugliness of these words is not described in a way that seems inherent. They are "Misshapen, split-gut, tortured, twisted words." All four of these imply a sort of violence, in order for something to be "misshapen" it must first be shaped, "split-gut" implies the gut was once whole, "tortured" innately implies a torturer, and "twisted" continues to imply some sort of violence. The implication here is that not only has violence been done to the soul (or the form of the soul), but that the words it looks for are ones that have experienced violence themselves. 
the "Guardian of souls" is "yielding" to new words- an act that does not imply a specific outcome. One possibility is that this "yielding" is what allows for this branding of a "form" on the soul. The Guardian's failure allows this supplementary form to be branded on Kabnis' soul. This helps illuminate the importance of the line "I want to feed the soul- I know what that is; the preachers don't- but I've got to feed it (111, emphasis mine). Without the exploration of "it" and the relationship this has to "Conversion," this line seems to be self-contradictory. Kabnis seems to be claiming to want "to feed the soul" but that he has "got to feed it." Syntactically "it" seems to be referring back to the soul, but with the preceding lines, it becomes apparent that "it" is actually the form branded on his soul. Kabnis wants to feed the soul, but the form prevents him from doing that. In this way, the "form" is being substituted in for the "soul," through its forced substitution of ugly words for beautiful language. Kabnis attempts to feed the soul beautiful words, and instead feeds the form ugly words. Both the words and the destination for the words are substituted by the "form” and the "form's” desire for ugly words.

The insert of "I know what that is: the preachers don't" ties this back to "Conversion." The preachers become symbolic of religious language, specifically of Christian language- and are unable to "know" the soul. This can be read as simple ignorance, but a more compelling argument is that their grounding in Christianity makes it impossible to distinguish the "form" from the "soul. If "Conversion" and conversion to Christianity marks the creation of this form, then it is born of Christianity. The preachers (whose only form of language is Christian language) would inevitably confuse the "form” from the "soul.” Kabnis may be prevented in feeding the soul, but he claims that he at least knows the difference, while the preachers are not even able to know the soul. 
Kabnis' concept of the form and the soul seems reminiscent of Du Bois’ concept of a double-consciousness, and the struggles that accompany it. The experience of being "Negro" and “American,” according to Du Bois, creates a “double-consciousness” a "sense of always looking at one's self through the eyes of others, of measuring one's soul by the tape of a world that looks on in amused contempt and pity. One ever feels his two-ness, -an American, a Negro; two souls” (Du Bois 3). This double consciousness, like Kabnis' “form”, stems from the internal and the external being in conflict. The double sense of self comes from seeing oneself, but also always seeing how you are seen, and finding the two to be consistently different.

This could also be described as having a second consciousness branded on the first. Assuming humans are born with a single consciousness, the second comes from a knowledge of the world's perception. This second consciousness is branded on top of the first, making it difficult to distinguish one from the other- much like the dynamic between Kabnis' form and Kabnis' soul. When placed next to Du Bois, Kabnis's diatribe becomes an exploration of how this double-consciousness affects the individual's relationship to his or her own soul and language.

Kabnis' indebtedness to Du Bois is something that is often overlooked by critics. Critiques of Kabnis often paint him as a man who fails due to his lack of understanding of the soul, his attempt to conceive of the soul as a personal, individual entity. Mary Battenfeld, in her essay ““Been Shapin Words T Fit M soul’: Cane, Language, and Social Change” explores Kabnis through this lens. Battenfeld examines how Kabnis fails to enact any sort of social change through his use of language.

Battenfeld's argument hinges on the idea of the soul, and the relationship between language and the soul. Kabnis' failure, according to Battenfeld, stems primarily from an 
improper understanding of the soul itself. Kabnis' attempt to shape words to fit his soul assumes an individual soul, the soul as solely his own, and because of this he is unable to wield any power with his speech. "Kabnis calls himself an orator," Battenfeld claims "but he is only interested in shaping his own soul, and so cannot be a socially and politically transformative speaker” (1243). Because Kabnis’ speech is individualistic, his focus limited to himself, he fails to enact any sort of change with his language. The political power of speech, according to Battenfeld's reading, relies on the community, on an "orally voiced soul of a people” (1243). Because Kabnis fails to listen to the community, and have the community inform his speech, he fails to create language capable of enacting social change.

While Battenfeld's claim that Kabnis fails to enact social change is valid, her exploration of why seems to miss the vital aspect of this "form." This leaves her otherwise sound theories lacking. Her analysis of why Kabnis fails is correct; his inability to listen to the community does make it impossible for his language to enact change. What she fails to account for is the reason for Kabnis' inability to listen to the community. The text suggests that this failure is not wholly Kabnis' fault; he does not listen because he cannot, not because he will not. The form intercepts the language that would otherwise be heard by his soul.

Battenfeld does, however, point to the issues raised in "Conversion" in her analysis of the final scene of "Kabnis"- a conversation between Kabnis and the old, deaf, and blind preacherFather John. Battenfeld illuminates what Father John is saying, and the implications it has for language and speech. "The sin whats fixed... upon the white folks.... - f telling Jesus-lies. O Th sin ' mitted $^{9}$ when they made th Bible lie" (Toomer 117). Battenfeld claims that this "sin" is

\footnotetext{
${ }^{9}$ By omitting the first part of the word here, Toomer allows for it to have multiple meanings. Contextually it seems as if the word is "committed," as Father John is speaking of the action of the sin. Sonically, however, the text implies the word "omitted," which carries very different connotations. By opening the sentence with "O" and then coming back to "'mittted" two syllables later, the word "omitted" is implied. The idea of omission doubles the effect
} 
rooted in the misuse of language; the sin is in the "act of 'tellin,' of distorting the language of the Bible to support the theory and practice of white supremacy.” (Battenfeld 1247). The sin rests in the shaping of language to fit specific roles and souls by the "white folks.” This is not wholly dissimilar from the issues raised in "Conversion.” The primordial "sin" is the misuse of language, it is the distortion of speech into "mere talk" (Arendt 180).

The language used to describe this speech act carries similar connotations to “Conversion” as well. Father John claims that "the white folks... made the Bible lie.” (Toomer 117). This is wildly different from lying about the Bible, the sin is not just the lie, but the act of making something holy, something non-human, perform the speech act. This seems very similar to the "Guardian of Souls” “yielding.” It is a non-human entity performing human functions, due to coercion. This makes Father John’s claim very similar to Kabnis’.

Kabnis, though indirectly, is pointing to how the yielding of "Conversion” creates the "form" on his soul. That is to say, Kabnis is pointing to how the misuse of religious language, the turning of religious "speech" into religious "talk" marks the creation of this form. This is the same sin that Father John is pointing out, the sin “'mitted when they made th Bible lie” (117). Kabnis, however, fails to use this moment of shared understanding.

The two men are making the same claim, and together could use that to spur on further thought, but Kabnis replies with "So thats your sin. All these years t tell us that the white folks made the Bible lie. Well, I’ll be damned. ... you old black fakir ${ }^{10}{ }^{\prime}$ (117). Instead of reveling in

of "tellin Jesus-lies," the sin of omission is the sin of non-disclosure, the sin of substituting "talk” for "speech.” By keeping the meaning ambiguous, the text keeps the idea of the committed sin, and also gestures towards the embedded omission of that sin.

${ }^{\mathbf{1 0}}$ Here the use of dialect complicates the reading. Kabnis is either insulting Father John by calling him a "fucker," with the spelling reflecting the dialect/pronunciation, or he is calling him a "fakir"- a term meaning "an indigent person, but specially applied to a Mahommedan religious mendicant” (OED). Fakir is a term usually reserved for Muslim ascetics who live solely off alms, and often denotes someone who prays by constantly repeating the name of 
this moment where there is a shared understanding, Kabnis attacks Father John, thereby destroying any possible communal speech. This elicits the response (from the character of Carrie) “Brother Ralph, is that your best Amen ${ }^{11}$ ?” (117).

This idea of a "best Amen" is the crux of why Kabnis fails. He is presented with a moment where he could act in concert ${ }^{12}$ with Father John, but instead he focuses on the fact that he himself has come to the same conclusion. Kabnis is valuing his own individuality over the collective experience. He attacks Father John, not because he disagrees, but because he sees no novelty in the claim. Kabnis already believes what Father John is saying, and believes that he himself has come to the same conclusions. Instead of focusing on this shared understanding, he places the value in the fact that he has already reached this understanding. He refuses to have any “Amen;” he uses this moment to foreground his individual intelligence, not to work with another. This is the moment where Kabnis fails. The previous attempts at shaping the individual soul can be read as admirable, they are attempts at re-shaping a soul that has been misshapen. This is attempted through individual language because Kabnis does not trust the language of the

God. Given Toomer's spiritual involvement with the Gurdjieff movement, (which often draws comparisons to the practices of Fakirs) this likely refers to Fakir in the religious sense, not to profanity (Turner 3).

${ }^{11}$ Amen is defined as "1. A concluding formula" and " 2 . A solemn expression of concurrence in, or ratification of, a prayer, or wish; Be it so really!" The key to this as a question of communal speech is in the second definition. Amen is something that is vocalized by multiple people as a ratification of a prayer, that is to say in order for the prayer to be completed. Carrie is then asking Kabnis to complete Father John's prayer with him, his Amen would be a communal act that would give the prayer power.

${ }^{12}$ This moment exemplifies the Arendtian concepts of speech, power, and authority. First there is the fact that the speech act is not ratified with the Amen, leaving as a powerless utterance. Because Kabnis does not vocalize an "Amen" the speech act is non-communal, and therefore non-active. Because of this there is no power in this speech act, as there need to be multiple participating parties for a speech act to have power. This moment also shows how Arendt's conception of authority works, and how authority fails. Authority, according to Arendt, refers to any institution or person that has "unquestioning recognition from those who are asked to obey; neither coercion nor persuasion is needed" (Arendt On Violence 45). Father John, theoretically, has the authority to call for an Amen. However, by dismissing this call, Kabnis destroys Father John's authority. If no one respects Father John's authority, he ceases to have it. This moment shows how powerless authority fails. The title alone is not enough to persuade Kabnis to listen to Father John's authority, and so he rebels against it, and in doing so destroys it. Father John, through his call for an Amen, has the authority to call out for speech- by denying it, Kabnis turns that into "talk." This shows that authority alone is not enough to provide social change, there must also be power. 
community surrounding him. The mistrust of the preachers makes sense, they are re-committing the "white-folks" sin. In this moment with Father John, however, Kabnis is speaking to another soul that understands him, the two men are saying the same thing- it is a moment that is worthy of an "Amen."

After verbally attacking Father John, Kabnis crumples. He "sinks to his knees... ashamed, exhausted” (117). Here the text is physically showing the failure of Kabnis' speech act. There is no redemption from his attack on Father John, instead it causes him to fall, to fail. He fails to figuratively stand with Father John, which in turn makes him fail to stand at all. This cements Kabnis' failure. Not only are we presented with a moment where there is a missed potential for action, but the text explicitly states that Kabnis falls, creating a physical failure to highlight the broader social failure.

Kabnis then leaves, leaving Carrie and Father John alone in a "soft circle" of light. Here Carrie’s “lips murmur, 'Jesus, come’” (117). Though it is not directly saying “Amen,” this is Carrie’s attempt at vocalizing her "best Amen." Battenfeld uses this passage to illuminate the fact that no "literary, religious or political messiah appears," but that instead "Toomer leaves us with a glorious ‘birth-song”” (Battenfeld 1247). Carrie’s “best Amen” does not usher in a messianic figure, but it does gesture towards something hopeful.

Battenfeld's reading of the last lines of Cane states "this ending implies that the 'best Amen’ will come from a community that, like Father John, ‘hears, an sees too.” The emphasis here is on the community, the claim being that if there is to be change it will not be because of an individual messianic figure, but from a community- from the power of communal speech. Cane is pointing not to change, but to the potential for change. Kabnis' failure demonstrates the limitations and failures of individual language, which shows that if there is to be change it will 
not come from an individual orator. The turn to the "birth-song" does not imply that change has occurred because of communal language, but that there is still the potential for change via communal language.

The ending of "Kabnis" is not the first iteration of this claim; it is explored at the end of the first section of Cane as well. The first section concludes with the story Blood-Burning Moon, which describes a love-triangle between a black woman, Louisa, and her two suitors, one blackone white. Towards the end of the story, the black man (Tom Burwell) kills the white man, (Bob Stone), and is then brutally lynched by the townspeople.

If "Kabnis" is concerned with the failure of individual language when juxtaposed against communal speech, Blood-Burning Moon is concerned with the danger of silence- with communal language as a potential shield. The scene describing the mob forming and the lynching of Tom Burwell is heavily muted, which highlights the dangers of silence.

White men like ants upon a forage rushed about. Except for the taut hum of their moving, all was silent... They came together. The taut hum rose to a low roar. Then nothing could be heard but the flop of their feet... the moving body of their silence preceded them... It flattened the Negroes beneath it. It rolled to the wall of the factory, where it stopped (36).

The text is placing the agency of the silence itself over the agency of the people engulfed in it. The only sound we get is a "taut hum" of moving, which is a distinctively nonspecific form of sound. A "taut hum" does not stem from a single agent, but is rather a collection of sounds moving together. A hum seems to be the sound closest to silence, a low sound that does little to disclose what is creating it. This "taut-hum" is displaced by a "low roar" which is then replaced by "the moving body of their silence." This silence is 
then given the agency, the mob being an agent of the silence instead of vice-versa. The silence "flattened the Negroes" the silence "rolled to the wall of the factory." Here the men inside of this silent body are not given agency, instead it is given to the silence itself $^{13}$. This silent body morphs into a mob with a single yell, which then burns Tom Burwell alive.

After the lynching the text returns to Louisa who is compelled to sing to the moon. "The full moon, an evil thing, an omen, soft showering the homes of folks she knew. Where were they, these people? She'd sing, and perhaps they'd come out and join her. Perhaps Tom Burwell would come. At any rate, the full moon in the great door was an omen which she must sing to" (36). Like the end of “Kabnis”, the end of BloodBurning Moon turns toward song as a possible redemption. With Kabnis the limitations of an individually conceived speech (of Arendtian “talk”) are explored, and there is a turn towards the sun and the possible redemption through communal speech. With BloodBurning Moon, there is an exploration of silence's role in violence, and a turn at the end to the moon and an attempt at redemption through singing, through a communal speech act.

The two moments are very similar, they are explorations in potential failures or dangers of speech, with a turn to a potentially better form of speech. Though neither makes a claim about a communally vocalized speech act serving as redemption, both moments hold the possibility of redemption. Blood-Burning Moon shows how silence is

\footnotetext{
${ }^{13}$ Once again it seems necessary to turn towards Arendt. In The Human Condition Arendt states "only sheer violence is mute" (26), linking the concepts of muteness and violence. The mob is silent because the mob is violent. The mob is composed of silence because the mob is composed of violence. The mob exists only for the use of violence, and because of this, it is an entirely silent mob.
} 
violence; “Kabnis” claims that individual language fails. Both claim that communal language has not yet succeeded, but that it still has the potential.

This mirrors Arendt's conception of speech acts. The individualistic speech of “Kabnis” is “mere-talk,” and as such cannot be powerful. The silence of Blood-Burning Moon is "violence" and "violence alone can never be great" (Arendt 26). The desire for a communal version of speech is a desire for Arendt's conception of a speech act, it is a desire for the communal aspect that is necessary for speech to conduct itself like action. The communal speech acts cannot fail, because they have not yet happened. The text places them as potential saviors; if these speech acts were to occur, perhaps something powerful would happen.

Cane as an entire text seems to perform the same functions as the "birth-song" at the end of Kabnis, as Louisa's song at the end of Blood-Burning Moon. As a text it cannot know what its own outcome will be; it cannot know what it will help to construct. It asks the reader to sing with it, to help co-construct it, but does not coerce the reader into doing so. It offers the reader a chance to share its song, to participate in its power. It offers is the potential for a communal voice; it offers the reader a chance to sing the "birth-song” with it. This does not imply change, but implies the possibility of speech, the possibility of power, the possibility of action.

Hannah Arendt's philosophy is embedded within Cane, which is an odd statement. The fact that Cane was written forty years before either of the books by Arendt complicates the idea that it exemplifies her philosophies. However, both Arendt and Toomer are concerned with the human condition, both Arendt and Toomer are attempting to unpack what makes the "best Amen." By dealing with the human as such, Toomer 
(likely unknowingly), unearthed the same concepts that Arendt later gave language to. “Conversion” shows what coercive strength looks like when vocalized. "Kabnis" shows the differences between individualistic "talk" and communal "speech.” The moment with Father John shows what the failures of "talk" and "authority" look like. "Blood-Burning Moon” shows the silence of violence, it shows how muted violence is when used.

The similarities between the two figures heightens the legitimacy of both. The fact that Toomer shows these ideas through intimate scenes of humans, lends credence to the idea that these concepts are innately human. Cane can be read as evidence for Hannah Arendt. A man with no possible knowledge of Arendt wrote a book that happens to show what Arendt later posited. The fact that these two figures (that were likely unaware of each other) mined for knowledge of humanity and found the same ore, adds validity to both of their claims. Without knowing it, these two figures voiced a communal "Amen," vocalized a reading of humanity with each other, and performed a true and powerful speech act. 


\section{Bibliography}

Akoma, Chiji. Folklore in New World Black Fiction. Columbus. The Ohio State University Press, 2007. Print

Arendt, Hannah. On Violence. New York: Harcourt, Brace, Jovanovich, 1970. Print.

Arendt, Hannah. The Human Condition. Chicago. The University of Chicago Press, 1958. Print.

Battenfeld, Mary. “'Been Shapin Words T Fit M Soul’: Cane, Language, and Social Change.” Callaloo, 25.4 (2002): 1238-1249. Print.

Derrida, Jacques. Of Grammatology. Baltimore: Johns Hopkins UP, 1976. Print.

Toomer, Jean. Cane. New York: Norton \& Company, 1988. Print

Toomer, Jean, and Darwin T. Turner. The Wayward and the Seeking: A Collection of Writings by Jean Toomer. Washington: Howard UP, 1980. Print. 